\title{
Long-term ophthalmologic examinations of eyes with equine recurrent uveitis after pars plana vitrectomy
}

\author{
Eva I. A. Baake', Myriam von Borstel', Karl Rohn², Michael H. Boevé and Bernhard Ohnesorge' \\ Clinic for Horses' and Institute for Veterinary Biometry and Epidemiology², University of Veterinary Medicine Hannover, Foundation, Hannover, Germany
}

\begin{abstract}
Summary: Equine recurrent uveitis (ERU) is an ocular disease in horses of different breeds with a prevalence between 2.7 and $7.6 \%$ in Europe and vitrectomy is a common method of treatment. The objective of the study was to evaluate the long-term retention of vision and control of uveitis after pars plana vitrectomy performed between 2005 and 2013 on eyes with a history of equine recurrent uveitis (ERU). Vitrectomy in eyes with ERU can influence the recurrent nature of the disease. Previous studies indicated success rates regarding the further absence of uveitis between 73.6 and $97.7 \%$. Owners of the horses were contacted and an ophthalmological reexamination including tonometry, induction of mydriasis, slit lamp biomicroscopy and direct ophthalmology was performed in 116 horses (147 eyes vitrectomized). Visual acuity was examined by the dazzle reaction and the menace response. Aspects such as gender, age and breed of the horses, as well as leptospiral status and preexisting damage of operated eyes are described. A total of 246 eyes were accessible for follow-up information, whereas 147 eyes were available for ophthalmologic reexaminations. If only the reexamined eyes are considered, an improvement of the condition was seen in 133 eyes (91\%) and 14 eyes (9\%) showed at least one uveitic recurrence after vitrectomy. A positive menace response and a positive dazzle reaction were observed in 128 of the 147 reexamined eyes (87\%). The number of episodes prior to vitrectomy, the gender of the horse and the leptospiral status of the eye showed no significant correlation with the prevalence of recurrences. Coat color, breed and age of the horse operated, and preexisting ocular alterations showed a significant influence on the chance of postoperative recurrences of uveitis. Horses with a coat color other than "chestnut" and "black and brown" had significantly more recurrences and odds ratio for these horses developing recurrences was also significantly higher. The present study shows that a large number of reexamined eyes remained visual (87\%) and a large proportion of the eyes (91\%) showed an improvement of the condition after vitrectomy. Results of this study suggest that genetic factors, age and preexisting ocular alterations influence the long-term prognosis of eyes with ERU after vitrectomy.
\end{abstract}

Keywords: eye, uveitis, vitrectomy, equine recurrent uveitis, ERU, leptospires, horse, equine

Citation: Baake E. I. A., von Borstel M., Rohn K., Boevé M. H., Ohnesorge B. (2019) Long-term ophthalmologic examinations of eyes with equine recurrent uveitis after pars plana vitrectomy. Pferdeheilkunde 35, 220-233; DOI DOI 10.21836/PEM20190303

Correspondence: Dr. Eva I. A. Baake, University of Veterinary Medicine Hanover, Clinic for horses, Buenteweg 9, 30559 Hanover, Germany; eva.ingrid.agnes.baake@gmail.com

Submitted: April 1, 2019 | Accepted: April 15, 2019

\section{Introduction}

Equine recurrent uveitis (ERU) is an ocular disease in horses of different breeds with a prevalence between 2.7 and $7.6 \%$ in Europe (Alexander und Keller 1990, Szemes and Gerhards 2000). Recurrent episodes of intraocular inflammation are painful, can lead to chronic damage to ocular structures and, hence, impair vision sooner or later (Angelos et al.1988, Gerhards and Wollanke 2001, von Borstel et al. 2005, Wollanke and Gerhards 2009). The impact of ERU on affected horses and their owners regarding the impairment of vision, the loss of use and the financial loss is significant (Gerding and Gilger 2016). The immediate therapeutic target during an acute episode of ocular inflammation is to control the pain and keep the damage to intraocular structures as little as possible by minimizing the ocular inflammation immediately. This can be accomplished by using local mydriatic cycloplegics, topical corticosteroids and systemic nonsteroidal anti-inflammatory drugs. In addition to the acute therapy, only the prevention of future recurrences can effectively prevent further intraocular damage (Curling $2011)$. In addition to enucleation, vitrectomy, the implantation of a cyclosporine drug delivery device and intravitreal injection of a low-dose gentamicin are currently the only therapeutic modalities that may prevent recurrences (Werry and Gerhards 1991, Werry and Gerhards 1992, Winterberg and Gerhards 1997, Frühauf et al. 1998, Gilger and Allen 1998, von Borstel et al. 2005, Gilger et al. 2010, Tömördy et al. 2010, Dorrego-Keiter et al. 2017, McMullen 2015, Kleinpeter et al. 2019, Fischer et al. 2019).

Equine recurrent uveitis is categorized into three different clinical subtypes in literature: The "classic ERU," the "posterior $E R U$ " and the "insidious ERU." If horses show acute and painful episodes of intraocular inflammation affecting posterior and anterior parts of the eye, with recurrence after non-inflammatory episodes, ERU is considered to be the "classic ERU." If intraocular inflammation is primarily affecting the vitreous body, choroid and retina, it is considered to be "posterior ERU." This type of ERU is seen mostly in Warmbloods, draught breed horses and horses imported from Europe to the USA. "Insidious ERU" is characterized as a mild and almost painless intraocular inflammation, regularly seen in the Appaloosa and draft horses in the USA (Gilger 2010).

Vitrectomy (single port, double port) in equine eyes suffering from ERU has been performed in Europe for more than two decades. During vitrectomy, the vitreous and the inflamma- 
tory debris it contains is mostly replaced by a buffered salt solution with glutathione, sodium bicarbonate and glucose ${ }^{12}$, mixed with gentamicin ${ }^{14}$ (Werry and Gerhards 1991, Werry and Gerhards 1992, Frühauf et al. 1998, von Borstel et al. 2005). Initially, vitrectomy was expected to reduce and alleviate recurrences, but not to prevent them entirely (Werry and Gerhards 1991). It was shown subsequently that vitrectomy was able to alter the recurrent nature of the disease in most cases and, therefore, prevent additional ocular pain and damage to intraocular structures (Werry and Gerhards 1992, Winterberg and Gerhards 1997, Frühauf et al. 1998). In addition to preservation of vision, it has been implemented in the literature over the years that the vitrectomy is only deemed successful when no uveitic recurrences occur postoperatively (von Borstel et al. 2005, Tömördy et al. 2010).

Seven studies have been published regarding the long-term prognosis after vitrectomy since 1991 (Werry and Gerhards 1992, Winterberg and Gerhards 1997, Frühauf et al. 1998, von Borstel et al. 2005, Tömördy et al. 2010, Dorrego-Keiter et al. 2017, Schinagl 2017). No recurrences of uveitic symptoms were recognized in these studies in a range between 73.6 (Tömördy et al. 2010) and 97.7\% (Winterberg and Gerhards 1997) of the eyes evaluated. These variations may be due to different patient populations, operating methods, periods between the surgery and the follow-up, or variations in study design. The aim of the current study was to provide a differentiated long-term prognosis based mainly upon ophthalmologic reexaminations and depending on gender, age and breed of each horse, the leptospiral status and preexisting alterations in eyes that underwent a double-port pars plana vitrectomy.

\section{Materials and methods}

A total of 284 eyes from 235 horses were vitrectomized between 2005 and 2013 at the equine clinic of the University of Veterinary Medicine of Hannover. Signalment and clinical data were collected from medical records.

\section{Study population}

All horses had a clinical history of at least two uveitic episodes of unknown etiology according to the referring veterinarian. A complete ophthalmologic examination was performed by a German veterinarian specialist for ophthalmology, including slit lamp biomicroscopy, direct ophthalmoscopy and tonometry in the clinic for horses prior to the vitrectomy to evaluate the extent of ocular changes and the current inflammatory status of the eye to determine the indication for vitrectomy. Mydriasis was performed in every patient for the preoperative examination. Vitrectomy was only performed in eyes without any signs of active intraocular inflammation.

Horses were stabled two days prior to the vitrectomy. Preoperative topical treatment consisted of ophthalmic ointment containing dexamethasone, neomycin and polymyxin $\mathrm{B}^{1}$ eight times a day and atropine ophthalmic drops ${ }^{2}(0.5 \%, q .12 \mathrm{~h})$. Horses were held off feed for about $6 \mathrm{~h}$ prior to the vitrectomy. Flunixin-meglumine ${ }^{3}$ was administered intravenously in a dosage of $1.1 \mathrm{mg}$ per $\mathrm{kg}$ body weight approximately $1 \mathrm{~h}$ prior to the surgery. In addition, sulfadimethoxine and trimethoprim ${ }^{4}$ was administered orally in a combined dosage of $20 \mathrm{mg}$ per $\mathrm{kg}$ body weight about $3 \mathrm{~h}$ prior to the surgery.

\section{Surgical procedure}

Horses were placed under general anesthesia in lateral recumbency with the affected eye facing up. The eyelashes were cut and the nasolacrimal duct and the conjunctival sac were flushed with a mild antibacterial solution containing sodium chloride, sodium mono- and dihydrogen phosphate and benzalkonium chloride ${ }^{5}$, subsequently, with a $1 \%$ povidoneiodine solution and, finally, with saline solution mixed with gentamicin 6 ( $4 \mathrm{mg} / \mathrm{ml}$ ) (Frühauf et al. 1998, von Borstel et al. 2005). The eye was surgically draped and an eye speculum was used to open the eyelids. A conjunctival flap was prepared to expose the sclera 11 to $13 \mathrm{~mm}$ from the limbus at the area of the pars plana ciliaris with the base of the flap away from the limbus (Werry and Gerhards 1991, von Borstel et al. 2005). Two intrascleral cruciate sutures ${ }^{7}$ were preplaced at the sclerotomy site at the 11 and $1 o^{\prime}$ clock position to allow a fast closure after removal of instruments (Frühauf et al. 1998, von Borstel et al. 2005). A lancet-shaped blade was used to prepare the two transscleral ports to enable a double-port vitrectomy (Werry and Gerhards 1992, von Borstel et al. 2005). The temporal sclerotomy was used as an irrigation port. The vitrectomy handpiece ${ }^{8}$ of an oscillating vitrector was entered into the vitreous cavity through the nasal sclerotomy port. An indirect binocular ophthalmoscope ${ }^{9}$ was used to visualize the vitrectomy tip through the dilated pupil to control the vitrectomy procedure (Frühauf et al. 1998, von Borstel et al. 2005). All accessible vitreal material, especially uveitic effusions, was aspirated and replaced by buffered saline solution ${ }^{10}$ mixed with gentamicin' ${ }^{6}(160 \mu \mathrm{g} / \mathrm{ml})$. The vitreous cavity was flushed with 250 to $500 \mathrm{ml}$ of the flushing solution, depending on the amount of vitreal material that needed to be removed. Both sclerotomies were closed immediately with the two preplaced intrascleral cruciate sutures after the removal of the vitrectomy handpiece and irrigation port. The conjunctiva was closed with a continuous suture ${ }^{11}$ and $40 \mathrm{mg}$ of gentamicin ${ }^{6}$ and $4 \mathrm{mg}$ of dexamethasone ${ }^{12}$ were injected into the ventral subconjunctiva (von Borstel et al. 2005).

Vitrectomized eyes were reevaluated every day during hospitalization by slit lamp biomicroscopy and direct ophthalmoscopy. In straightforward cases, topical therapy with ophthalmic ointment containing dexamethasone, neomycin and polymyxin $B^{1}$ was conducted $\mathrm{q}$. $3 \mathrm{~h}$ for five days postoperatively, q. $6 \mathrm{~h}$ for another seven days and q. $8 \mathrm{~h}$ for another 14 days subsequently at the home stable. Oral flunixin-meglumine ${ }^{13}$ therapy was continued until one day postoperatively at the full dosage $(1.1 \mathrm{mg} / \mathrm{kg}$ body weight $\mathrm{q} .12 \mathrm{~h}$ ) and the second and third day postoperatively at the half dosage $(0.55 \mathrm{mg} / \mathrm{kg}$ body weight q. $12 \mathrm{~h}$ ). Sulfadimethoxine and trimethoprim 4 were administered for four days (20 mg/kg q. $12 \mathrm{~h}$ ).

Vitreal samples were obtained during the first few seconds after the start of the vitrectomy via the specimen collection vial of the vitrectomy system. Vitreous material was immediately sent to an external laboratory ${ }^{14}$ to perform a microscopic agglutination test (MAT) for intraocular leptospiral antibodies 
and a polymerase chain reaction (PCR) detecting leptospiral DNA. A total of 254 vitreous samples were available for MAT and PCR.

\section{Intra- and postoperative complications}

Intra- and postoperative complications throughout hospitalization were documented and evaluated.

\section{Contacting for reexamination}

Owners were contacted by telephone and interviewed for the current study with the aid of a standardized questionnaire. They were asked about the postoperative clinical course of the vitrectomized eye/eyes, whether any signs of ocular inflamma- tion or other ocular problems had been noticed and/or may have been diagnosed by a veterinarian. Three different options were used to differentiate between possible outcomes: free of complaints (FOC), recurrences (REC) or non-specific ocular inflammatory symptoms (NOIS), such as conjunctivitis or keratitis (Table 1). After answering the questionnaire, the owners were offered an ophthalmologic checkup of their horse at their home stable.

The ophthalmologic examination was performed by a veterinarian (first author) trained by a German veterinarian specialist of ophthalmology, and by an ECVO-certified ophthalmologist. A complete ophthalmologic examination was executed to evaluate the vitrectomized eyes for the current study and included tonometry, induction of mydriasis using tropicamide ${ }^{15}$, slit lamp biomicroscopy and direct ophthalmoscopy. The findings were documented and an ERU score established previ-

Table 1 Possible postoperative outcomes after the vitrectomy | Mögliche postoperative Ergebnisse nach der Vitrektomie

postoperative progression of ERU

signs of ocular inflammation, similar to the episodes prior to the vitrectomy

mild signs of ocular inflammation, not comparable to the episodes prior

to the vitrectomy (e.g. epiphora, chemosis, due to conjunctivitis, keratitis)

no signs of ocular inflammation abbreviation

REC (recurrence of uveitis)

$\left.\begin{array}{c}\text { NOIS } \\ \text { (non-specific ocular inflammatory symptoms) } \\ \text { FOC (free of complaints) }\end{array}\right\} \quad \begin{gathered}\text { IMP } \\ \text { (improvement) }\end{gathered}$

Table 2 Score for chronic uveitis findings of the most affected ocular compartements (Score by M. von Borstel [18, 19]) | Score für chronische Uveitis-Befunde der am meisten betroffenen Augenabschnitte

\begin{tabular}{|c|c|c|c|c|c|}
\hline score & iris & lens & vitreous & fundus oculi & other chronic changes \\
\hline 0 & no abnormality detected & no abnormality detected & no abnormality detected & no abnormality detected & no abnormality detected \\
\hline 1 & $\begin{array}{l}\text { low-grade depigmenta- } \\
\text { tion; focal small synechia }\end{array}$ & $\begin{array}{c}\text { focal capsular cataract; } \\
\text { focal iris residues }\end{array}$ & $\begin{array}{l}\text { low-grade liquefication } \\
\text { with several floating fil- } \\
\text { amentous strands of cell } \\
\text { debris and inflammatory } \\
\text { products }\end{array}$ & $\begin{array}{l}\text { single focal } \\
\text { chorioretinopathy („, bullet } \\
\text { hole lesion“) }\end{array}$ & $\begin{array}{l}\text { low-grade reduction in } \\
\text { size of the bulb/reduc- } \\
\text { tion in size of the anterior } \\
\text { chamber }\end{array}$ \\
\hline 2 & $\begin{array}{c}\text { low-grade depigmenta- } \\
\text { tion; focal large-scale } \\
\text { synechia }\end{array}$ & $\begin{array}{l}\text { multifocal capsular/sub- } \\
\text { capsular cataract; local } \\
\text { bullous subcapsular/cor- } \\
\text { tical cataract; multifocal } \\
\text { iris residues }\end{array}$ & $\begin{array}{l}\text { low-grade liquefication; } \\
\text { several curtain-like } \\
\text { strands of cell debris and } \\
\text { inflammatory products }\end{array}$ & $\begin{array}{c}\text { a few focal } \\
\text { chorioretinopathies } \\
\text { ("bullet hole lesion"); } \\
\text { small-area peripapillary } \\
\text { chorioretinopathy ("but- } \\
\text { terfly lesion") }\end{array}$ & $\begin{array}{c}\text { moderate reduction in } \\
\text { size of the bulb/reduction } \\
\text { in size of the anterior } \\
\text { chamber; local corneal } \\
\text { haze }\end{array}$ \\
\hline 3 & $\begin{array}{c}\text { moderate depigmen- } \\
\text { tation; several focal } \\
\text { synechiae }\end{array}$ & $\begin{array}{c}\text { local reticular capsular/ } \\
\text { subcapsular cataract; } \\
\text { local immature corticale/ } \\
\text { nuclear cataract }\end{array}$ & $\begin{array}{c}\text { moderate liquefication; } \\
\text { moderate curtain-like } \\
\text { strands of cell debris and } \\
\text { inflammatory products; } \\
\text { low grade diffuse yellow } \\
\text { haze }\end{array}$ & $\begin{array}{c}\text { multiple focal } \\
\text { chorioretinopathies; } \\
\text { large-scale peripapillary } \\
\text { chorioretinopathy }\end{array}$ & $\begin{array}{l}\text { low-grade bulb enlarge- } \\
\text { ment of the anterior; } \\
\text { laminar corneal haze; } \\
\text { low-grade increase in } \\
\text { intraocular pressure }\end{array}$ \\
\hline 4 & $\begin{array}{c}\text { moderate depigmenta- } \\
\text { tion; atrophy; circular } \\
\text { synechiae }\end{array}$ & $\begin{array}{l}\text { diffuse immature capsu- } \\
\text { lar/subcapsular/cortical } \\
\text { and/or nuclear cataract; } \\
\text { lens subluxation }\end{array}$ & $\begin{array}{l}\text { high-grade liquefication; } \\
\text { moderate curtain-like } \\
\text { strands of cell debris and } \\
\text { inflammatory products; } \\
\text { moderate diffuse yellow } \\
\text { haze }\end{array}$ & $\begin{array}{l}\text { laminar } \\
\text { chorioretinopathies/ } \\
\text { laminar degeneration of } \\
\text { the retina; peripapillary } \\
\text { wrinkles of the retina; } \\
\text { partial retinal detachment }\end{array}$ & $\begin{array}{l}\text { moderate bulb enlarge- } \\
\text { ment/enlargement of the } \\
\text { anterior chamber; lami- } \\
\text { nar coreal haze/haab`s } \\
\text { sriae; moderate increase } \\
\text { in intraocular pressure }\end{array}$ \\
\hline 5 & $\begin{array}{l}\text { high-grade depigmenta- } \\
\text { tion; seclusio pupillae }\end{array}$ & $\begin{array}{l}\text { mature/hypermature } \\
\text { cataract; lens luxation }\end{array}$ & $\begin{array}{l}\text { high-grade liquefica- } \\
\text { tion; high-grade visible } \\
\text { strands of cell debris and } \\
\text { inflammatory products; } \\
\text { high-grade diffuse yellow } \\
\text { haze }\end{array}$ & $\begin{array}{c}\text { complete retinal detach- } \\
\text { ment }\end{array}$ & $\begin{array}{l}\text { high-grade bulb enlarge- } \\
\text { ment/enlargemenet of } \\
\text { the anterior chamber; } \\
\text { laminar corneal haze/ } \\
\text { haab's striae; high-grade } \\
\text { increase in intraocular } \\
\text { pressure; phtisis bulbi }\end{array}$ \\
\hline
\end{tabular}


ously was used to estimate the status of each eye. The score was applied for different ocular compartments (iris, lens, vitreous and fundus oculi) and for other chronic changes and resulted in a total score for each eye. Values ranged from zero (no abnormality detected) to five (high-grade abnormalities) (Table 2) (von Borstel et al. 2010, Kulbrock et al. 2013b). This score system was also applied retrospectively to acquire a preoperative score for each eye based on examinations documented before the vitrectomy.

\section{Statistical evaluation}

Statistical analysis was performed with the SAS Enterprise Guide 7. $1^{16}$. The binomial distribution was used to assess the age distribution among the horses vitrectomized. Fisher's ex-

Table 3 Gender, breed and coat color distribution of the vitrectomized horses and the patient population of the clinic for horses between 2005 and 2013 | Geschlechts-, Rassen- und Fellfarbenverteilung der vitrektomierten Pferde und der Patientenpopulation der Klinik für Pferde zwischen 2005 und 2013

\begin{tabular}{|c|c|c|c|c|}
\hline \multirow[b]{2}{*}{ gender } & \multicolumn{3}{|c|}{$\begin{array}{l}\text { vitrectomized } \\
\text { horses }\end{array}$} & \multirow{2}{*}{$\begin{array}{c}\text { patient population, } \\
\text { clinic for horses Universi- } \\
\text { ty of Veterinary Medicine } \\
\text { Hannover } \\
\text { (n/\%) }\end{array}$} \\
\hline & $\mathrm{n}$ & (\%) & & \\
\hline mares & 102 & $(43)]$ & \multirow{2}{*}{ ** } & $(6827 / 53)$ \\
\hline geldings & 109 & $(46)=$ & & $(4341 / 34)$ \\
\hline stallions & 24 & (10) & $* * *$ & $(1749 / 14)$ \\
\hline female & 102 & \multicolumn{2}{|l|}{ (43) } & (6827/53) \\
\hline male & 133 & \multicolumn{2}{|l|}{ (56) } & $(6090 / 47)$ \\
\hline breed & $\mathrm{n}$ & \multicolumn{2}{|l|}{ (\%) } & $(n / \%)$ \\
\hline Warmbloods & 123 & \multicolumn{2}{|l|}{$(52.3)$} & $(7941 / 62.1)$ \\
\hline Icelandic horses & 32 & (13.6) & & ]$^{\sin (584 / 4.6)}$ \\
\hline ponies & 29 & (12.3) & & * $\quad(1492 / 11.7)$ \\
\hline Frisian horses & 10 & (4.3) & & $(325 / 2.5)$ \\
\hline Trotters & 9 & (3.8) & & $(138 / 1.1)$ \\
\hline $\begin{array}{l}\text { Pura Raza } \\
\text { Espanola }\end{array}$ & 7 & (3) & J* & $(154 / 1.2)$ \\
\hline $\begin{array}{l}\text { Quarter horse / } \\
\text { paint }\end{array}$ & 6 & $(2.6)$ & & $(408 / 3.2)$ \\
\hline Arabic horses & 5 & $(2.1)$ & & $(457 / 3.6)$ \\
\hline Knabstruppers & 3 & (1.3) & & $(24 / 0.2)$ \\
\hline Thoroughbred & 3 & (1.3) & & (503/3.9) \\
\hline Pinto & 1 & $(0.4)$ & & $(50 / 0.4)$ \\
\hline others & 7 & (3) & & (711/5.5) \\
\hline coat color & $\mathrm{n}$ & (\%) & & $(n / \%)$ \\
\hline black \& brown ${ }^{+}$ & 135 & (57) & & $(5513 / 50)$ \\
\hline others $^{++}$ & 53 & (23) & & $(3077 / 28)$ \\
\hline chestnut & 47 & (20) & & $(2527 / 22)$ \\
\hline
\end{tabular}

${ }^{*} \mathrm{p}<0.05,{ }^{* *} \mathrm{p}<0.01,{ }^{* * *} \mathrm{p}<0.001$ (fisher's exact test); ${ }^{+}$brown, black-brown, black; ${ }^{++}$gray, dappled, others, undocumented act test was used to evaluate the frequency of distribution in the group of horses vitrectomized between 2005 and 2013 and the patient population in the clinic for horses during the same period. Since not all vitrectomized eyes were available for follow-up information, two distinct groups were created to further specify and verify information. One group consisted of all horses with follow up information (A) and one only of the horses with ophthalmologic reexaminations (B). Fisher's exact test and the chi-squared test were used to evaluate the dependence of various characteristics on the frequency of REC and NOIS. The group NOIS was tested combined with REC against FOC and was tested combined with FOC against REC. The Wilcoxon signed-rank test was performed to evaluate the trends between the height of the pre- and postoperative ERU scores. Odds ratios were used to estimate the influence of leptospiral antibodies and leptospiral DNA detectable on the appearance of REC and NOIS.

\section{Results}

\section{Patient population}

The retrospective patient population was composed of various breeds and comprised 102 mares (124 eyes), 109 geldings (132 eyes) and 24 stallions (28 eyes). The major proportion of the vitrectomized horses were colored "black and brown" (57\%) (Table 3). Most horses were between four and seven years old $(106 / 235)$ at the time of vitrectomy of the first eye (Table 4).

Horses with an age between four and seven years old were significantly overrepresented compared to every other age group ( $\leq 0.0001$ ) (Table 4). Compared to the patient population in the clinic for horses between 2005 and 2013, vitrectomy was significantly more often performed in male than in female horses (males: $p=0.0037$; geldings: $p=0.0049$; stallions: $p=0.0001)$ and significantly more often in Icelandic horses $(p \leq 0.0001)$, Friesian horses $(p=0.0411)$, Trotters $(p=0.0004)$, Pura Raza Española $(p=0.0118)$ and Knabstruppers $(p=0.0061)$ than in Warmbloods (Table 3). More than half of the horses vitrectomized were Warmbloods $(52.3 \%, 123 / 235)$. The most frequent coat color among the horses vitrectomized in this study was "black and brown" and these were vitrectomized significantly more often than horses with the coat color "other" $(p=0.031)$, when compared to

Table 4 Age distribution of the vitrectomized horses Altersverteilung der vitrektomierten Pferde

\begin{tabular}{cccc}
\hline age group & age in years & $\mathrm{n}$ & $(\%)$ \\
\hline 1 & $0-3$ & 27 & $(11,5 \%)$ \\
2 & $4-7$ & 106 & $(45,1 \%)$ \\
3 & $8-11$ & 47 & $(20 \%)$ \\
4 & $12-15$ & 33 & $(14 \%)$ \\
5 & $16-19$ & 15 & $(6,4 \%)$ \\
6 & $20-23$ & 6 & $(2,6 \%)$ \\
7 & $24-27$ & 1 & $(0,4 \%)$ \\
8 & $\geq 28$ & 0 & $(0 \%)$ \\
\hline
\end{tabular}


Fig. 1 Overview of the horses and eyes available for follow-up and for ophthalmologic check-up | Übersicht über die Pferde und Augen, die kontaktiert und zur ophthalmologischen Untersuchung zur Verfügung standen

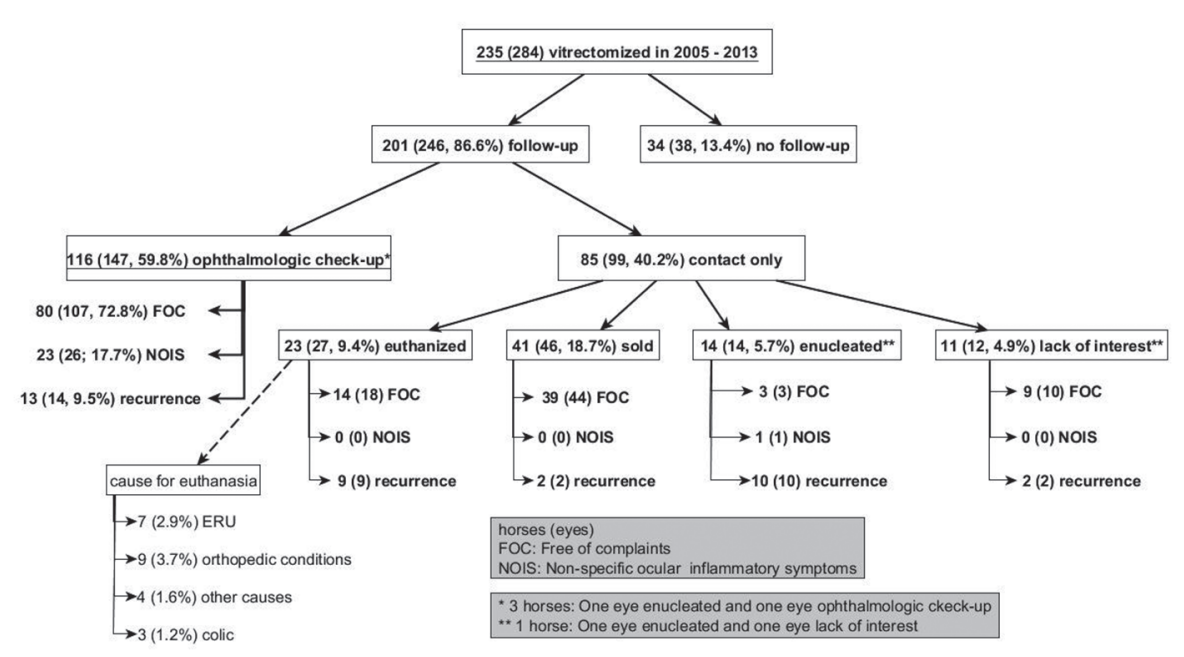

of the condition was achieved in $91 \%(133 / 147)$ of the eyes (IMP), whereas $9 \%(14 / 147)$ of the eyes showed signs of ocular inflammation similar to the episodes prior to the vitrectomy (REC). Considering all the eyes where information was available, $74 \%(182 / 246)$ were FOC and $11 \%(27 / 246)$ were categorized as NOIS, therefore, $85 \%$ (209/246) of the eyes were categorized as IMP, while REC was shown in $15 \%$ $(37 / 246)$ of the eyes. No significant differences between the follow-up group (A) and the ophthalmologic checkup group (B) could be shown (Fig. 2).

\section{Stratification}

Because not all the vitrectomized horses were available for follow-up information, the information available was stratified for different factors that could not affect the outcome of the vitrectomized eyes. This was carried out to verify the success rates concerning the absence of uveitic symptoms after the vitrectomy.

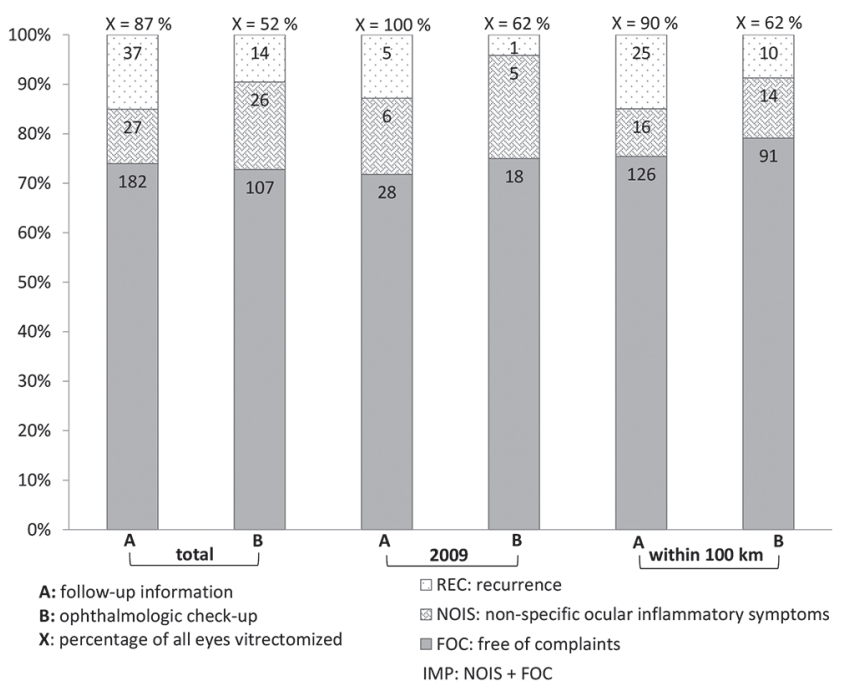

Fig. 2 Number of eyes categorized as "FOC" (free of complaints), "NOIS" (non-specific ocular inflammatory symptoms) and "REC" (recurrence of uveitis), stratified by year and two different radii around the clinic | Anzahl der Augen, klassifiziert als "FOC" (beschwerdefrei), "NOIS" (unspezifische okuläre Entzündungssymptome) und "REC" (Wiederauftreten der Uveitis), nach Jahr und zwei verschiedenen Radien um die Klinik herum geschichtet 
This group of eyes was used for stratification because $100 \%$ of the horses vitrectomized from the year $2009(n=39)$ were available for follow-up information (Fig. 2).

In addition, the owner's place of residence was used to further stratify the follow-up information. A radius of $100 \mathrm{~km}(90 \%$ follow-up rate) around the clinic was used. No significant differences could be shown between both stratifications (total vs. 2009 and within $100 \mathrm{~km}$ ) or between the ophthalmologic checkup group (B) and the follow-up and ophthalmologic checkup group $(A)$.

\section{ERU Score}

All reexamined eyes were scored with the ERU score (Table 1). This post-vitrectomy score was compared to the pre-vitrectomy score, which was based on the examinations documented prior to the vitrectomy. The Wilcoxon signed-rank test showed no significant differences between the total score from pre- $(2.8 \pm 1.1)$ to post-vitrectomy $(2.9 \pm 1.2)$ for the reexamined eyes (B). The lens score increased significantly from pre- $(1.5 \pm 1.1)$ to post-vitrectomy $(2.8 \pm 1.3)$, whereas the vitreous score decreased significantly from pre- $(2.5 \pm 1.3)$ to post-vitrectomy $(1.7 \pm 1.7)$. All other compartments showed no significant changes from pre- to post-vitrectomy.

\section{Sight}

A negative dazzle reaction combined with a negative menace response was observed in $4 \%(6 / 147)$ and a positive dazzle reaction combined with a negative menace response was observed in $9 \%(13 / 147)$ of the eyes reexamined (B). One of the six eyes with a negative dazzle reaction and a negative menace response had a fundus score of 5, which was defined as a complete retinal detachment, and the other five horses had a lens score of 5, which was defined as a mature or hypermature cataract or a lens luxation (Table 1).

The group of eyes with a positive dazzle reaction combined with a negative menace response had four eyes with a lens score of 4 (diffuse immature capsular/subcapsular/cortical and/or nuclear cataract; lens subluxation), eight eyes with a lens score of 5 and one eye with a fundus score of 4 (laminar chorioretinopathies/laminar degeneration of the retina; peripapillary wrinkles of the retina; partial retinal detachment).

\section{Number of uveitis episodes}

The number of uveitis episodes pre-vitrectomy did not influence the occurrence of REC significantly.

\section{Gender, breed, coat color, age}

The gender did not influence the rate of REC significantly $(p>0.05)$. Overall, $17 \%$ of the female eyes showed REC $(18 / 103)$ and $83 \%$ of the female eyes improved after the vitrectomy (IMP: 85/103; FOC: 68/103, NOIS: 17/103). The number of REC was $13 \%(19 / 143)$ in vitrectomized eyes of male horses and $87 \%$ of the eyes of male horses improved after the vitrectomy (IMP: 124/143; FOC: 114/143; NOIS: 10/143).

All Knabstruppers (3/3) in the present study showed REC and were, therefore, excluded from the further statistics. The breed did not influence the rate of REC significantly $(p>0.05)$.

Significantly more REC were noticed in the eyes of horses with the coat color "other" $(12 / 55,22 \%)$ compared to the eyes of horses with a "black and brown" coat color (15/141, $11 \%$ ) $(p=0.0264)$. The coat color "other" included horses with the coat colors gray, dappled and undocumented colors and the breed, Knabstruppers being excluded from the statistics, did not influence the rate of recurrences significantly.

Older horses tended to have more REC than younger horses. Horses older than 20 years showed a significantly higher number of eyes with REC compared with horses aged four to seven years ( $p=0.0477$ ) (Fig. 3).

\section{ERU score and time point of recurrence}

The higher the preoperative ERU score, the higher the rate of REC. Eyes with a total score of three and five had significantly more REC than horses with a score of two $(p=0.0112$, $p=0.0212$, respectively) (Fig. 4).

The mean time between the vitrectomy and the first REC was 12.8 ( \pm 22.8 ) months. The latest onset of REC was 95 months after the vitrectomy; this was observed in two eyes. A total of 17 REC (6.9\%) were noticed during the first two months. Six REC occurred between the third and the sixth month post-vitrectomy. The Kaplan-Meier value showed that the probability of a non-recurrence of intraocular inflammation after vitrec-

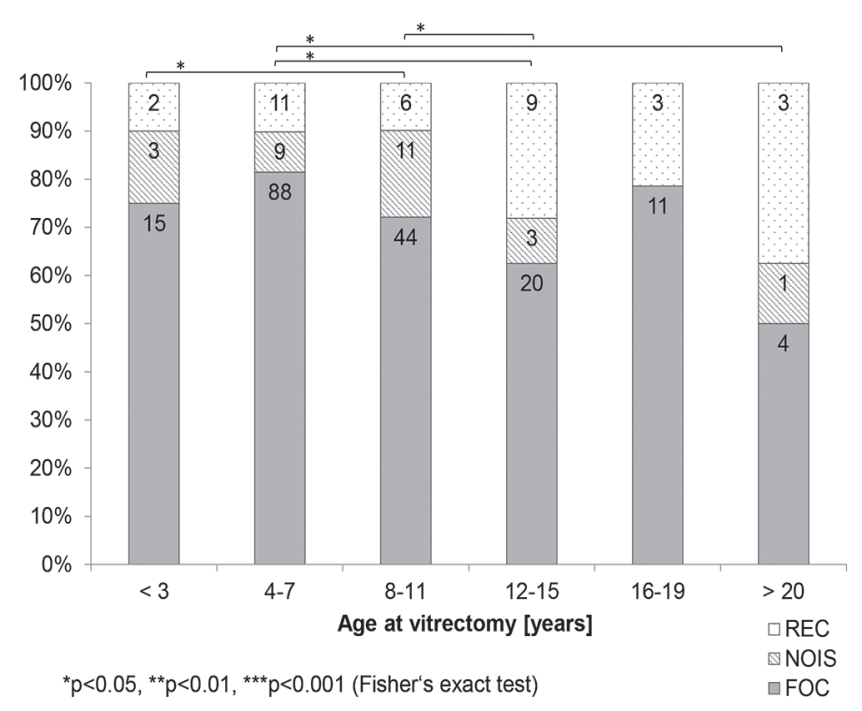

Fig. 3 Number of eyes with "FOC" (free of complaints), "NOIS" (non-specific ocular inflammatory symptoms) and "REC" (recurrence of uveitis) by age at vitrectomy | Anzahl der Augen mit "FOC" (beschwerdefrei), "NOIS" (unspezifische okuläre Entzündungssymptome) und "REC" (Wiederauftreten der Uveitis) nach Alter bei der Vitrektomie 
tomy decreased over time. The highest decrease happened during the first two months. After 20 months, the probability seemed to reach a plateau, which dropped down again after about 50 months. After 123 months, the probability of a non-recurrence was $80.79 \%$ (Fig. 5).

\section{Leptospiral status}

Horses younger than three years were significantly more often leptospiral-positive than horses aged 12 to 15 years $(p=0.0176)$ and older than 20 years $(p=0.0014)$ (Fig. 6). The color distribution showed no significant differences between the age groups.

Leptospiral-negative eyes (16/98, 16\%) did not show significantly more recurrences than leptospiral-positive eyes $(13 / 121,11 \%)$.

The odds ratio of developing REC after a vitrectomy was higher (not significantly) for leptospiral-negative eyes (OR: 1.925, $\mathrm{Cl}: 0.8988,4.1228)$. Horses where a serovar other than serovar Grippotyphosa was detected, had a higher odds ratio

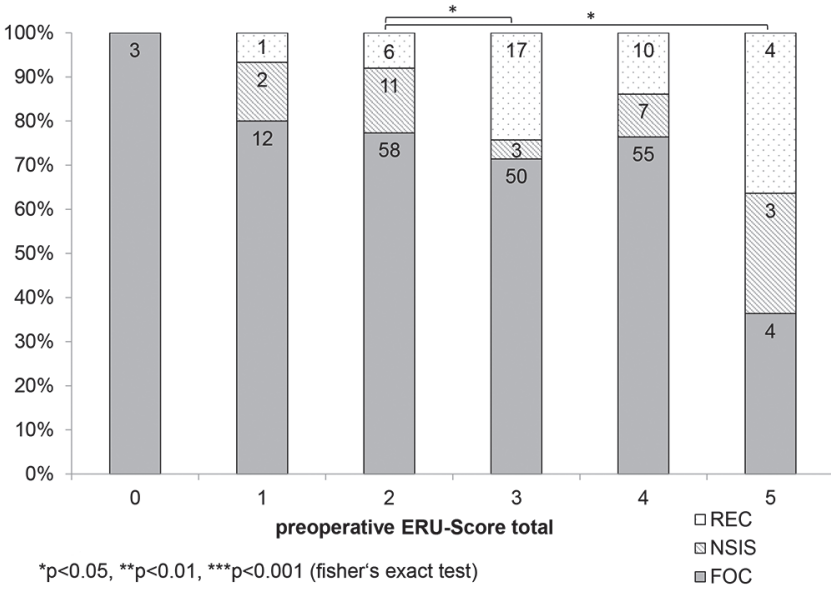

Fig. 4 Number of eyes with FOC" (free of complaints), "NOIS" (non-specific ocular inflammatory symptoms) and "REC" (recurrence of uveitis) by ERU-score at vitrectomy | Anzahl der Augen, klassifiziert als "FOC" (beschwerdefrei), "NOIS" (unspezifische okuläre Entzündungssymptome) und "REC" (Wiederauftreten der Uveitis), nach ERU-Score bei der Vitrektomie

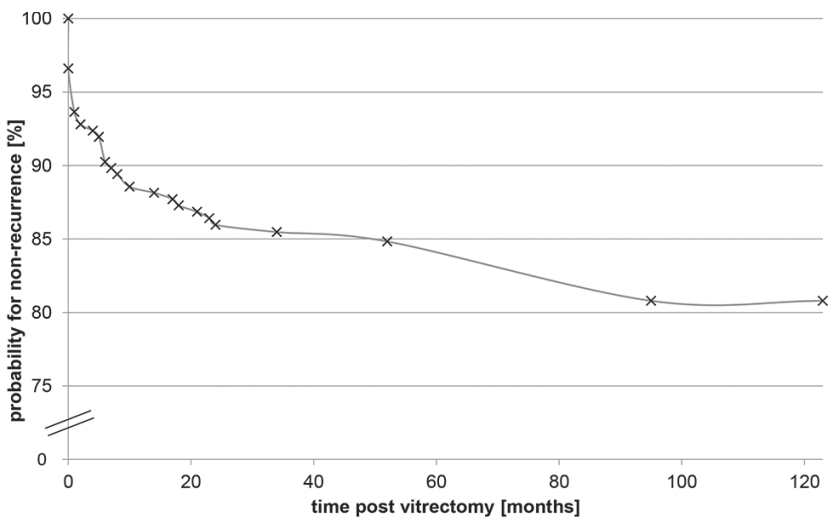

Fig. 5 Kaplan-Meier estimation of the probability for non-recurrence after vitrectomy | Kaplan-Meier-Schätzung der Wahrscheinlichkeit eines Nicht-Wiederauftretens nach Vitrektomie of developing REC than horses where serovar Grippotyphosa was detected (OR: 2.1667, Cl: 0.6065, 7.7407). The odds ratio of developing REC was also higher for Warmbloods when the eyes were leptospiral-negative (OR: $2.087, \mathrm{Cl}$ : $0.6945,6.2713)$. Icelandic horses had a higher odds ratio of developing REC than Warmbloods (OR: 1.4637, Cl: 0.5289, 4.0504). None of the latter odds ratios were significant. The odds ratio was significantly higher of developing REC for the coat color "other" than for the coat colors "chestnut" or "black and brown" (OR: 2.6321, Cl: 1.2596, 5.5003) (Fig. 7).

The outcome of the vitrectomy regarding the absence of recurrent episodes (REC) was tested for Warmbloods and Icelandic horses depending upon the leptospiral status of the vitrectomized eyes.

The rate of IMP (improvement) was $88 \%$ (121/137) for all Warmblood horses and $84 \%$ (31/37) for all Icelandic horses. When only leptospiral-positive eyes were included, the rate of IMP was lower (79\%) for Icelandic horses (15/19) than for Warmblood horses (64/70; $91 \%)$. This difference was not significant ( $p=0.999)$.

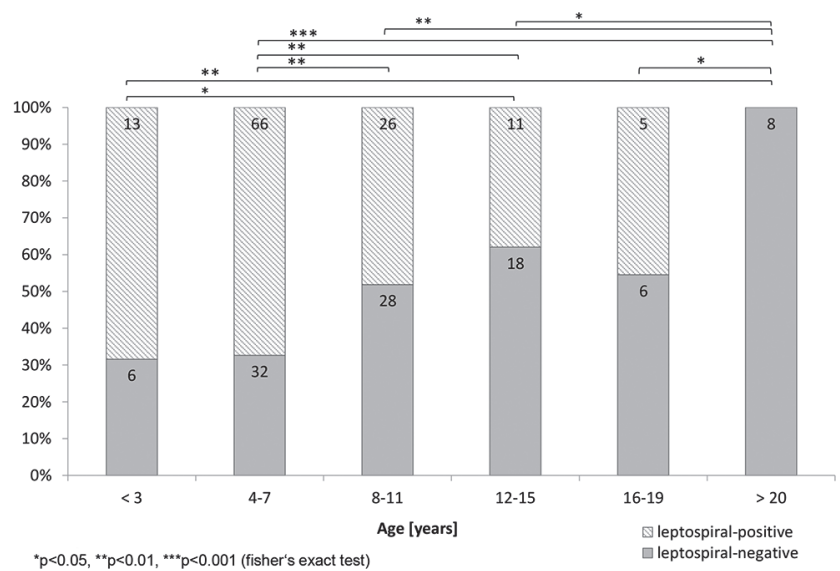

Fig. 6 Distribution of leptospiral-positive and leptospiral-negative eyes between different age groups | Verteilung der leptospiren-positiven und leptospiren-negativen Augen zwischen verschiedenen Altersgruppen

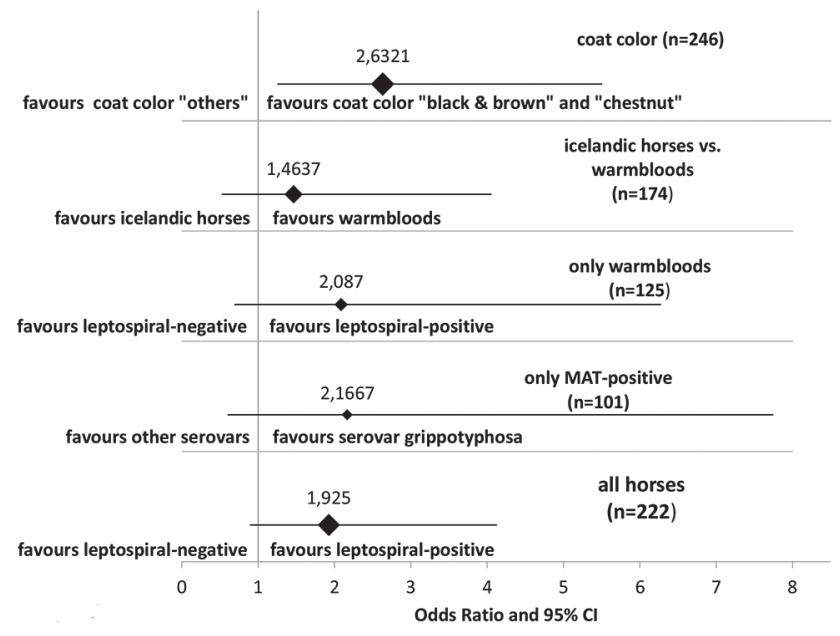

Fig. 7 Forest diagram showing the odds ratios of having a "REC" (recurrence of uveitis) between different stratifications | Forest Diagramm, das die Quotenverhältnisse eines "Rezidivs" (Wiederauftreten der Uveitis) zwischen verschiedenen Schichten zeigt 


\section{Discussion}

Follow-up surveys are the only way to provide a prognosis for horses with ERU that are going to have a vitrectomy. It is in the nature of follow-up surveys that not all subjects are available for follow-up information, and even fewer are available for follow-up examinations. Therefore, the rates for non-recurrence of uveitic symptoms in literature ranged between 73.6 and $97.7 \%$ (Table 5) (Werry and Gerhards 1992, Winterberg and Gerhards 1997, Frühauf et al. 1998, von Borstel et al. 2005, Tömördy et al. 2010, Schinagl 2017). These rates were based on ophthalmologic reexaminations in only four of seven studies, with the other studies not indicating how many horses were reexamined as part of the study design (Winterberg and Gerhards 1997, Frühauf et al. 1998, Dorrego Keiter et al. 2017, Schinagl 2017). Most information in the latter studies was gained through interviewing the owners by telephone (von Borstel et al. 2005, Tömördy et al. 2010). The number of eyes evalvated in these studies was between 10 and 134, and the period between the vitrectomy and the follow-up ranged between 2 and 216 months. Only two studies gave a median time of 29 and 87 months of the evaluation after the vitrectomy (Dorrego Keiter et al., 2017 Schinagl 2017). No recurrences of uveitic symptoms were recognized in these studies in a range between 73.6 (Tömördy et al. 2010) and 97.7\% (Winterberg and Gerhards 1997) of the eyes evaluated. These variations may be due to different patient populations, operating methods, periods between the surgery and the follow-up, or variations in study designs.

The aim of the current study was to obtain information of and to perform a reexamination on as many eyes as possible after a period of at least 17 and up to 123 months post-vitrectomy. Follow-up information for $86.6 \%$ (246/284) of all eyes vitrectomized between 2005 and 2013 was available. A total of $59.8 \%$ (147/246) of these eyes were available for ophthalmologic reexaminations and 40.2\% (99/246) were contacted only via telephone (Fig. 1).
Ophthalmologic checkup group (B) vs. follow-up information group (A)

The number of eyes with REC was smaller in the ophthalmological checkup group (B: 9\% REC) compared to the follow-up information group (A: 15\% REC). This may be partly explained by the numbers of enucleation and euthanasia in the "information only" group (Fig. 2). Since any episode of uveitis may result in globe destruction and loss of vision and since uveitis in equines is generally highly painful, euthanasia may have been a reasonable choice for owners in these cases (Gerding and Gilger 2016).

Since the ophthalmological reexamination for the current study was performed only once, it could not be clarified at what exact time after the vitrectomy the eyes showed recurrences. However, it could be shown that 17 of 35 REC happened during the first two months after vitrectomy (Fig. 5). In the current study the probability of REC increases with time.

Whether NOIS is accounted for in the group of REC or the group of FOC could not be finally clarified. An argument that NOIS needs to be numbered among FOC is that inflammatory ocular signs of eyes with NOIS were certainly distinguished by owners from the episodes prior to the vitrectomy and that veterinarians diagnosed another ocular problem in the eyes of their horses besides uveitis (e.g. keratitis, conjunctivitis). Owners of a vitrectomized horse were presumably very sensitively attuned to recognizing signs of ocular inflammation in their horse. This aspect may provide a bias in the "information only" group. A certain expectation of the owners regarding the success of the vitrectomy should not be underestimated. The FOC and NOIS (IMP) together represented $85 \%(209 / 246)$ of the eyes vitrectomized (Fig. 2). Regarding the studies published about the longterm prognosis after vitrectomy, the rate for non-recurrence as FOC only ranged between 73 and $74 \%$ and confirmed the results of Tömördy et al., who found a rate of non-recurrence of $73.6 \%$ and of Dorrego-Keiter et al. with a rate

Table 5 Published studies regarding the long-term prognosis of horses with ERU after a vitrectomy | Veröffentlichte Studien zur Langzeitprognose von Pferden mit ERU nach einer Vitrektomie

\begin{tabular}{|c|c|c|c|c|c|}
\hline & evaluated eyes & $\begin{array}{c}\text { time post } \\
\text { vitrectomy [months] }\end{array}$ & $\begin{array}{l}\text { opthalmological } \\
\text { reexaminations }\end{array}$ & $\begin{array}{l}\text { no uveitic } \\
\text { symptoms }\end{array}$ & $\begin{array}{l}\text { conservation of visual } \\
\text { acuity (not blind) }\end{array}$ \\
\hline $\begin{array}{l}\text { Werry } \\
\text { et al. } 1992\end{array}$ & $90.9 \%(10 / 11)$ & not specified & not specified & $100 \%$ & no information \\
\hline $\begin{array}{l}\text { Winterberg } \\
\text { et al. } 1997\end{array}$ & $53.1 \%(43 / 81)$ & 6 to 67 & $100 \%$ & $97.7 \%$ & $72 \%(31 / 43)$ \\
\hline $\begin{array}{l}\text { Frühauf } \\
\text { et al. } 1998\end{array}$ & $89.5 \%(34 / 38)$ & 5 to 60 & $79 \%$ & $85 \%$ & $85 \%(29 / 34)$ \\
\hline $\begin{array}{l}\text { Borstel } \\
\text { et al. } 2005\end{array}$ & $89.3 \% \quad(50 / 56)$ & 2 to 3 & not specified & $94 \%$ & $80 \%(40 / 50)$ \\
\hline $\begin{array}{l}\text { Tömördy } \\
\text { et al. } 2010\end{array}$ & $89.8 \% \quad(53 / 59)$ & 3 to 90 & not specified & $73.6 \%$ & no information \\
\hline $\begin{array}{l}\text { Dorrego-Keiter } \\
\text { et al. } 2017\end{array}$ & $100 \%(134 / 134)$ & $\begin{array}{l}8 \text { to } 54 \\
\text { median } 29\end{array}$ & not specified & $\begin{array}{c}76.3 \% \\
(\mathrm{FOC}+\mathrm{NOIS})\end{array}$ & no information \\
\hline $\begin{array}{l}\text { Schinagl } \\
2018\end{array}$ & $100 \%(654 / 654)$ & $\begin{array}{c}6 \text { to } 216 \text { median } \\
87,6\end{array}$ & $16 \%(105 / 54)$ & $96,3 \%$ & $81 \%(128 / 147)$ \\
\hline $\begin{array}{l}\text { Present study, } \\
\text { Baake } 2017\end{array}$ & $86.6 \%(246 / 289)$ & $\begin{array}{l}17 \text { to } 123 \\
\text { median } 64\end{array}$ & $59.8 \%(147 / 246)$ & $\begin{array}{c}91 \% \text { IMP } \\
73 \% \text { FOC / 18\% NOIS }\end{array}$ & $87 \%(128 / 147)$ \\
\hline
\end{tabular}


of non-recurrence of $77.6 \%$ (Tömördy et al. 2010, Dorrego Keiter et al. 2017). Dorrego-Keiter et al. stated clearly that they included eyes with ocular problems other than uveitis (e.g. keratitis, conjunctivitis) as a non-recurrence (Dorrego Keiter et al. 2017). If NOIS is counted among FOC, the rate for non-recurrence ranged between 85 and $91 \%$ in the present study, which is almost the same as the findings of Winterberg et al., Frühauf et al., von Borstel et al. and Schinagl (Winterberg and Gerhards 1997, Frühauf et al. 1998, Von Borstel et al. 2005, Schinagl 2017). Nevertheless, some results of previous publications differ from each other significantly. This may not only be explained by different time periods between the vitrectomy and the ophthalmologic follow-up examination for these studies, but also by the method of evaluation (ophthalmologic examination vs. contact only). Tömördy et al. (reexamined and contacted owners and referring veterinarians of the horses between 3 and 90 months post-vitrectomy, whereas Frühauf et al. examined 27 of 38 eyes of the horses vitrectomized between 5 and 60 months post-vitrectomy and von Borstel et al. reexamined or contacted owners after two to three months post-vitrectomy (Frühauf et al. 1998, von Borstel et al. 2005, Tömördy et al. 2010). Frühauf et al. reported that most of the REC were recognized during the first and second month post-vitrectomy (Frühauf et al. 1998). The present study confirmed that most of the REC occurred during the first two months post-vitrectomy (17 out of 35 eyes with REC) (Fig. 5). In addition, we also found that late REC occurred, as a total of 20 eyes with REC were noticed later than the second month post-vitrectomy in the present study. Two eyes even showed REC after 95 months, but these were the only REC that were recognized later than 60 months post-vitrectomy. This is in accordance with another study that showed two late recurrences at 30 and 60 months after the vitrectomy (Schinagl 2017). Assuming that the ocular examinations in the current study would have been performed only three months after each vitrectomy, the success rate (IMP) would have increased up to $93 \%$. Von Borstel et al. (2005) evaluated vitrectomized eyes only two to three months post-vitrectomy and, therefore, probably demonstrated a higher success rate $(94 \%)$ than in the present study (von Borstel et al. 2005). Since Tömördy et al. evaluated eyes up to 90 months post-vitrectomy, their rate for non-recurrence was less than that presented by von Borstel et al. (Von Borstel et al. 2005, Tömördy et al. 2010). The longer the postsurgical period reviewed and the more reexaminations performed, the lower the rates found for postsurgical non-recurrence are. This is contrary to Schinagl, who evaluated eyes up to 216 months post vitrectomy and showed a rate of non-recurrence of $96.3 \%$. But it has to be pointed out that only $16 \%$ of the evaluated eyes were ophthalmologically examined (Schinagl 2017). The Kaplan-Meier values provide the impression of a rapid decrease of REC during the first six months post-vitrectomy and a slower, but steady decrease of the probability of non-recurrence from 89 down to $80 \%$ during the time between 7 to 123 months (Fig. 5). Nevertheless, surgeons, surgical methods, patients and owners' compliance may have influenced the rate for non-recurrence as well.

A limitation of the present study was the fact that not all horses were available for an ophthalmological reexamination. Therefore, the actual rate of REC might be higher or low- er than determined. In addition, the memories of the owners may have been insufficient regarding the health issues of each horse. The information available was stratified by different factors (total, year 2009, radius of $100 \mathrm{~km}$ around the clinic) to minimize these limitations and to determine these influences. However, regardless of whether eyes were reexamined or information was only based on phone calls, the decision concerning the possible postoperative outcome of an eye was, in the end, always based upon the owner's statements.

No significant difference could be shown between the total number of REC and the two stratifications (100 km and the year 2009) (Fig. 2). Therefore, the assumption regarding the long-term prognosis in the current study was thought to be of high value.

\section{ERU subtypes and scoring}

In the literature, ERU is categorized into three different clinical subtypes: "classic ERU," "posterior ERU" and "insidious ERU." The "classic ERU" affects posterior and anterior parts of the eye, the "posterior ERU" affects primarily the vitreous body, choroid and retina, and the "insidious ERU" is characterized as a mild and almost painless intraocular inflammation (Gilger 2010). In the current study, the major proportion of the horses belonged to the subtype "classic ERU" or "posterior ERU." It can be assumed that the three Knabstruppers belonged to the subtype "insidious ERU," and these horses were, therefore, excluded from further statistics.

The total ERU score of all eyes examined from pre- to post-vitrectomy did not change significantly from pre- to post-vitrectomy in the current study, including the eyes with REC and NOIS. Since ophthalmologic changes tend to worsen in eyes with ERU during each inflammatory episode if they are not vitrectomized (Alexander and Keller 1990), this can be interpreted as another indication for the success of this surgery. Ocular inflammation did not seem to have worsened the ERU score further after the vitrectomy. The lens score increased significantly from a mean score of 1.5 to 2.8. Cataracts seemed to have an ongoing maturation and another study could show that 13 vitrectomized eyes had a progressive postsurgical cataract formation, 11 of which already showed incipient cataracts or vitreal inflammatory infiltrates adhered to the posterior capsule of the lens prior to the vitrectomy (Frühauf et al. 1998). The progressive nature of cataract formation in horses can be explained by alterations within the complex anatomy of the lens. If inflammatory debris, for example, was attached to the posterior lens capsule and removed within the vitrectomy, shear forces effected the hyaline membrane of the lens and the usually inactive lens epithelium might have been triggered to start mitosis and the newly formed cells might undergo hyaline degeneration, lipid metamorphosis and calcification (Cogan 1962). In another study, 2 out of 53 horses showed a cataract two months after the vitrectomy (von Borstel et al. 2005). The same authors described in a later study that the higher the preexisting ocular changes, the higher the odds for postsurgical complications, such as retinal detachment and progressive cataract formation (von Borstel et al. 2010). If lenses showed cataract formations prior to the surgery, the chance of postoperative progressive cataract formation was found to be high. 
It should be mentioned that none of the three eyes with a total ERU-Score of zero showed REC (Fig. 4), which might raise up the question whether these eyes might not have suffered from ERU. But the authors consider these horses to have ERU since all vitrectomized horses had a clinical history of at least two uveitic episodes of unknown etiology according to the referring veterinarian, who in some cases was one of the co-authors and surgeons. Two of these three eyes belonged to horses that already had a vitrectomy in the other eye and this might explain an early intervention. But regardless of these three eyes that might be questionable, it could be shown that eyes with a total ERU-Score of 3 and 5 had significantly more recurrences than eyes with a total ERU-Score of 2. This highlights that horses benefit from a vitrectomy at an early stage of ERU, as other authors already suggested (von Borstel et al. 2005).

Vitreal opacities due to inflammatory debris were the most common findings in eyes of horses with ERU (Bartel 2004, Wiehen 2012, Kulbrock et al. 2013b). The mean score of all eyes examined for the vitreous was 2.5 prior to the vitrectomy in the current study and decreased significantly to 1.7 after the vitrectomy. This was the principle alteration of the ERU score caused directly by the vitrectomy procedure.

The recurrent episodes of intraocular inflammation usually lead to a destruction of intraocular tissue. Equine recurrent uveitis has been described to be the most common cause of blindness in horses (Angelos et al. 1988, Lavach 1990). A recent study evaluated the prognosis and impact of ERU in the United States and reported a high frequency of blindness as well (Gerding and Gilger 2015). Vision has been reported to be maintained in 72 to $85 \%$ of the eyes with ERU that underwent a vitrectomy (Winterberg and Gerhards 1997, Frühauf et al. 1998). A more recent study evaluated the outcome of low-dose gentamicin injection in eyes with different stages of equine recurrent uveitis and showed that $70.5 \%$ (43 of 61 eyes) remained visual after this treatment (Kleinpeter et al. 2019). Winterberg et al. differentiated between an increase and decrease of vision after vitrectomy (Winterberg and Gerhards 1997). According to that study, an increase of vision occurred in $39.5 \%(17 / 43)$ of the eyes, whereas vision decreased in $32.6 \%(14 / 43)$ of the eyes and $27.9 \%$ of the eyes were blind after the vitrectomy. Von Borstel et al. reported that $20 \%(10 / 47)$ of the vitrectomized eyes showed a complete loss of vision post-vitrectomy (von Borstel et al. 2005). In the present study, a total of $87 \%(128 / 147)$ of the reexamined eyes had a positive dazzle reaction and a positive menace response. Only 3\% (5/147) of the reexamined eyes showed a negative dazzle reaction and $10 \%$ (14/147) of the eyes showed a negative menace response. It is not possible to state at what time point the eyesight was impaired after the vitrectomy. Further prospective studies need to reexamine vitrectomized eyes at certain time points after the vitrectomy.

\section{Gender}

Previous studies suggest that male horses suffer from ERU significantly more often than females (Wollanke 1995, Szemes and Gerhards 2000, Kulbrock et al. 2013, Dorrego-Keiter et al. 2016). Geldings have been reported to be affected significantly more often than mares and stallions (Szemes and Gerhards
2000). The present study verified these findings, because more male than female, and more geldings than mares and stallions were vitrectomized compared to the clinic population during the same time period (Table 3). Wollanke et al. demonstrated previously that the leptospiral antibody titers were similar for male and female horses (Wollanke 1995). Hence, these authors postulated a protective action of female hormones. Other uveitic diseases in human medicine have been described to be gender-predisposed. Morbus Behçet syndrome and Fuch's heterochromic cyclitis are two diseases seen in human patients that involve uveitic symptoms. These diseases were thought to be gender-related ( $O^{\prime}$ Brien et al. 1994), but recent studies have cast doubt whether gender influences exist in these diseases (Bonfioli et al. 2005, Davatchi et al. 2012). A different outcome after the vitrectomy between male and female horses seems to be altogether nonexistent in the present study, since the mean ERU score pre- and post-vitrectomy did not alter significantly between male and female horses.

\section{Breed, coat color and age}

In the current study, Icelandic and Friesian horses, Trotters, Pura Raza Española and Knabstruppers were significantly more often vitrectomized than Warmbloods compared to the clinic population (Table 3). This may well be due to a higher prevalence of ERU in these breeds. In a previous retrospective study, over one third of all horses with ERU were Icelandic horses (Wiehen 2012).

Appaloosas are significantly more likely to develop uveitis than Standardbreds and Thoroughbreds (McLaughlin et al. 1992). Dwyer et al. described that Appaloosas have an 8.3 times higher chance of developing uveitis than other equine breeds (Dwyer et al. 1995). A recent study showed that Appaloosas with equine recurrent uveitis had a significant risk of developing recurrences after intravitreal treatment with low-dose gentamicin (Fischer et al. 2019) and another study showed that leopard colored horses had a significantly higher risk to have a REC after vitrectomy (Schinagl 2017). One study evaluated the genetic risk factors for Appaloosas, such as a marker in the TRPM1 gene in the ECA1 region responsible for their spotted coat color and two different markers in the region for the equine major histocompatibility complex (Fritz et al. 2014). These and other authors were able to identify three markers in these regions that were significantly associated with ERU. A leopard complex spotting gene that is associated with a higher risk of ERU and congenital stationary night blindness in the horse was found in Knabstruppers (Bellone et al. 2013, Baumgart and Gerhards 2014, Fritz et al. 2014). In the present study, all Knabstruppers showed a postsurgical REC. This may be due to the different subtype of ERU in this breed and perhaps even due to a solely autoimmune or genetically triggered uveitis. Therefore, a long-term sustained cyclosporine implant may be the better choice of therapy in this breed (Gilger and Allen 1998, Gilger et al. 2000, Gilger et al. 2010, Baumgart 2014, Baumgart and Gerhards 2014). A genetic risk factor for developing ERU was also shown for Warmblood horses (Kulbrock et al. 2013a).

Since "insidious ERU" has been described as mild and painless, owners often do not recognize ocular changes until loss 
of vision occurs. "Insidious ERU" has less often been associated with an intraocular leptospiral infection in Appaloosas and Knabstruppers and a larger primarily immunological etiological component than in other breeds has, therefore, been assumed (Gilger et al. 2010, Baumgart 2014).

Horses were divided into the groups "black and brown," "chestnut" and "others" because of their different genetic patterns. The extension of black color in "black and brown" horses is determined by a homo- or heterozygote gene "E" (EE or Ee) and chestnut horses have a homozygous "ee" (Castle 1954). The group with the coat color "other" was affected by REC significantly more frequently in the present study than horses with a "black and brown" coat color. One reason for this may be that all horses with a spotted coat color were assigned to this group and, as outlined above, "spotted" horses appear to have a poorer prognosis concerning their rate of REC than single color horses. Horses with a black, brown and black-brown coat color ("black and brown") were vitrectomized significantly more often in the current study than horses with the coat color "other" (Table 3). This is in accordance with the higher occurrence of ERU among Warmbloods with a "black and brown" coat color (Kulbrock et al. 2013b). Other studies have demonstrated an overrepresentation of horses with ERU of a brown coat color as well (Bartel 2004, Wiehen 2012).

A total of $45.1 \%(106 / 235)$ of all horses vitrectomized were between four and seven years of age. This age group was significantly overrepresented compared to any other age group. Information about the prevalence of ERU among horses of different ages varies in literature. Some authors stated that relatively young horses were affected (Alexander and Keller 1990, Wollanke 1995), while others reported an increase of ERU among older horses, supposedly because of the cumulative contact to leptospiral antigens and antibodies during their lives (Szemes and Gerhards 2000, Bartel 2004). The current study implies that horses of an age between four and seven years are more likely to be vitrectomized. The reason for this may be that younger horses were more prone to develop ERU, that owners were more prone to invest in a vitrectomy in younger horses, or that referring veterinarians could diagnose ERU earlier than in older horses. Referring veterinarians may have recommended vitrectomy at an early stage of the disease, due to a better outcome at an early stage of the disease (von Borstel et al. 2010). In the present study horses older than 20 years showed a significantly higher number of eyes with REC compared with horses aged four to seven years. This is in accordance with a recent study from southern Germany, where older horses showed significantly more often REC than younger horses (Schinagl 2017).

\section{Leptospiral status}

One of the propagated etiological (infectious) factors for ERU in North-West Europe is an intraocular leptospiral infection. In previous studies, vitreous and aqueous humor of affected eyes has been analyzed by different methods, such as PCR, MAT and ELISA, to identify a potential intraocular infection with leptospires (Rimpau 1947, Heusser 1948, Halliwell et al. 1985, Sillerud et al. 1987, Schwink et al. 1989, Alexander and Keller 1990, Brem et al. 1998, Wollanke et al. 1998, Brem et al. 1999, Faber et al. 2000, Wollanke et al. 2000, Wollanke et al. 2001, Wollanke et al. 2004, Niedermaier et al. 2006, Brandes et al. 2007, Pearce et al. 2007, Gilger et al. 2008, Frellstedt 2009, von Borstel et al. 2010, Wiehen 2012, Polle et al. 2014, Gerding and Gilger 2015). In the present study, intraocular leptospiral infection was demonstrable through MAT and/or PCR in a total of $56 \%$ of the vitrectomized eyes. This finding is in accordance with a recent study performed in northern Germany in which 221 undiluted vitreal samples were examined by MAT and culturing. The MAT revealed that $57.7 \%$ of the samples were positive and $16 \%$ of the samples had a positive leptospiral culture (Dorrego-Keiter et al. 2016). It is still under discussion whether the prognosis is better in leptospiral-positive eyes after a vitrectomy. Tömördy et al. and Schinagl reported a higher number of eyes without recurrent episodes of uveitis if leptospiral antibodies were detectable (Tömördy et al. 2010, Schinagl 2017). In contrast to these studies, Dorrego-Keiter et al. demonstrated that there is no significant difference between the outcome of eyes tested negative and tested positive for leptospiral antibodies via MAT (Dorrego Keiter et al. 2017). All odds ratios calculated in the present study for eyes having a REC depending upon being leptospiral-positive or leptospiral-negative showed a $95 \%$ confidence interval below one. Hence, none of these odds ratios were significant, although the odds ratio for leptospiral-negative eyes having a REC was found to be higher (OR: 1.925). When Warmbloods are compared to Icelandic horses, independent of their intraocular leptospiral status, Icelandic horses are 1.4 times more likely to develop REC. Therefore, not only the intraocular leptospiral status, but also the breed appeared to have an influence on the prognosis after vitrectomy. Since these odds ratios were only tendencies and 82 of the leptospiral-negative eyes did not show any signs of REC, vitrectomy did not appear to be significantly less effective on leptospiral-negative than on leptospiral-positive eyes. If only leptospiral-positive eyes would have been included, the rate of non-recurrence would be slightly higher for Warmblood horses (64/70, $91 \%)$, but lower for Icelandic horses (15/19, $79 \%)$. The findings of the present study, therefore, support the concept that the etiology of ERU is multifactorial, and other factors influencing the long-term prognosis after a vitrectomy are most probably autoimmunogenic and genetically determined (Deeg et al. 2001, Deeg 2008, Gilger 2010, von Borstel et al. 2010, Kulbrock et al. 2013a).

\section{Alternative methods of treatment}

The currently most promising alternative treatment option of equine recurrent uveitis is the intravitreal injection of low-dose gentamicin. A recent study shows that up to $88,1 \%$ of 59 horses that received $4 \mathrm{mg}$ of intravitreal gentamicin did not show recurrent or persistent ocular inflammation with a minimum of 30 days between treatment and follow-up (Fischer et al. 2019). And another study showed that 91,8\% (56 of 61) treated eyes did not show ocular inflammation over a period that ranged between two and 96 months after treatment (Kleinpeter et al. 2019). The intravitreal injection of low-dose 
gentamicin may therefore be a considerable alternative treatment option of horses with equine recurrent uveitis.

\section{Conclusion}

This study showed that between $85 \%$ (74\% FOC, $11 \%$ NOIS) of the eyes evaluated and $91 \%$ (73\% FOC, $18 \%$ NOIS) of the eyes reexamined showed an improvement (IMP) of the recurrent uveitic episodes after the vitrectomy. A total of $87 \%$ $(128 / 147)$ of the reexamined eyes showed a positive dazzle reflex and a positive menace response after the vitrectomy at the time of ocular reexamination for the current study.

The odds of having a recurrence were higher if no leptospiral DNA or antibodies were detected. However, genetic and potentially autoimmunogenic factors, as well as age, breed and preexisting ocular damage appears to influence the long-term prognosis. Therefore, an early vitrectomy of horses with a reliable diagnosis of classic ERU should be advocated.

\section{Manfacturer's addresses}

1 IsoptoMax ${ }^{\circledR}$, Alcon, Freiburg, Germany

2 Atropin-POS ${ }^{\circledR} 0.5 \%$, Ursapharm Arzneimittel $\mathrm{GmbH}$, Saarbrücken, Germany

3 Flunidol $^{\circledR}$ RPS 50 mg/ml, CP-Pharma, Burgdorf, Germany

4 Sulfadimethixin \& Trimethoprim 50\% ${ }^{\circledR}$, Medistar $\mathrm{GmbH}$, Ascheberg; Germany

5 Ophtho Lavas, Vétoquinol $\mathrm{GmbH}$, Ravensburg; Germany

6 Gentamicin-ratiopharm ${ }^{\circledR} 80 \mathrm{mg} / 2 \mathrm{ml} \mathrm{SF}$, Ratiopharm GmbH, Ulm, Germany

7 Polysorb ${ }^{\circledR}$, 3/0 USP, Covidien Deutschland GmbH, Neustadt/Donau, Germany

8 Vitrektom, Erbe Elektromedizin, Tübingen, Germany

9 Heine Omega ${ }^{\circledR}$ 500, Heine Optotechnik, Herrsching, Germany

10 BSS PLUS ${ }^{\circledR}$, Alcon Laboratories, Inc., Texas, USA

11 Vicry $l{ }^{\circledR}, 4 / 0$, Ethicon, Norderstedt, Germany

12 Dexa-ratiopharm ${ }^{\circledR}$, Ratiopharm GmbH, Ulm, Germany

13 Flunidol $^{\circledR} 5 \%$ Gel, CP-Pharma, Burgdorf, Germany

14 IVD GmbH Hannover, Seelze-Letter, Germany

${ }^{15}$ Mydriaticum Stulln UD ${ }^{\circledR}$, Pharma Stulln GmbH, Stulln, Germany

16 SAS Institute Inc., Cary, NC, USA sumer Protection and Food Safety in accordance with the German Animal Welfare Law (LAVES - Reference number: Az. 14A 485).

\section{Statement of informed consent}

All owners provided informed consent that information can be included in the study.

\section{Conflict of interest statement}

The authors declare that they have no competing interests.

\section{Acknowledgements}

The authors thank language editor Philip Saunders for the validation of the English language used in this article.

\section{References}

Alexander C. S., Keller H. (1990) Ätiologie und Vorkommen der periodischen Augenentzündung des Pferdes im Raum Berlin. Tierärzłl. Praxis 18, 623-627

Angelos J., Oppenheim Y., Rebhun W., Mohammed H., Antczak D. F. (1988) Evaluation of breed as a risk factor for sarcoid and uveitis in horses. Anim. Gen. 19, 417-25

Baake E.I.A. (2017) Studie zur Ursache und Therapie der equinen rezidivierenden Uveitis. Wissenschaftliche Reihe der Klinik für Pferde, Band 31, Cuvillier Verlag, Göttingen, ISBN 3736986513, 9783736986510, 1-91

Baumgart A. (2014) Cyclosporin A und dessen möglicher Einsatz bei der Tigerschecken-Uveitis. Diss. Med. Vet. München

Baumgart A., Gerhards H. (2014) Besonderheiten der Tigerschecken-Uveitis und möglicher Cyclosporin A-Einsatz in der Therapie in Deutschland. Pferdeheilkunde 30, 626-632; DOI 10.21836/ PEM20140601

Bellone R. R., Holl H., Setaluri V., Devi S., Maddodi N., Archer S., Sandmeyer L., Ludwig A., Foerster D., Pruvost M., Reissmann M., Bortfeldt R., Adelson D. L., Brooks S. A. (2013) Evidence for a retroviral insertion in TRPMI as the cause of congenital stationary night blindness and leopard complex spotting in the horse. PloS One. 8, e78280; DOI 10.1371/journal.pone.0078280. eCollection 2013.

Bonfioli A. A., Curi A. L., Orefice F. (2005) Fuchs' heterochromic cyclitis. Sem. Ophthalm. 20, 143-146; DOI 10.1080 /08820530500231995

Brandes K., Wollanke B., Niedermaier G., Brem S., Gerhards H. (2007) Recurrent uveitis in horses: vitreal examinations with ultrastructural detection of leptospires. Transbound. Emerg. Diseas. 54, 270-275

Brem S., Gerhards H., Wollanke B., Meyer P., Kopp H. (1998) Demonstration of intraocular leptospira in 4 horses suffering from equine recurrent uveitis (ERU). Berl. Münch. Tierärztl. Wschr. 111 , 415-417

Brem S., Gerhards H., Wollanke B., Meyer P., Kopp H. (1999) 35 leptospira isolated from the vitreous body of 32 horses with recurrent uveitis (ERU). Berl. Münch. Tierärztl. Wschr. 1 12, 390-303

Castle W. E. (1954) Coat Color Inheritance in Horses and Other Mammals. Genetics 39, 35-44

Cogan D. G. (1962) Anatomy of lens and pathology of cataracts. Experiment. Eye Res. 1, 291-295

Curling (2011) Equine recurrent uveitis: Treatment. Comp. Cont. Educ. Vet. 33, E1
Information was obtained from client-owned horses during the study which has been approved by the ethics committee within the University of Veterinary Medicine, Hannover, and the State Office for Con- 
Davatchi F., Shahram F., Chams-Davatchi C., Sadeghi Abdollahi B., Shams H., Nadji A., Faezi T., Akhlaghi M., Ghodsi Z., Larimi R., Ashofteh F. (2012) Behcet's disease: is there a gender influence on clinical manifestations? Int. J. Rheumatic Dis. 15, 306-314; DOI 10.1111/j.1756-185X.2011.01696.x.

Deeg C. A. (2008) Ocular immunology in equine recurrent uveitis. Veterinary Ophthalmology 11 (SI), 61-65; DOI 10.1111/i.14635224.2008.00625.x.

Deeg C. A., Kaspers B., Gerhards H., Thurau S. R., Wollanke B., Wildner G. (2001) Immune responses to retinal autoantigens and peptides in equine recurrent uveitis. Investigative Ophthalm. Visual Sci. 42, 393-398

Dorrego Keiter E., Tóth J., Dikker L., Sielhorst J., Schusser G. F. (2017) Langzeitergebnisse der Pars-Plana-Vitrektomie in Abhängigkeit vom Leptospiren-Antikörper-Nachweis im Glaskörper bei 118 Pferden mit Equiner Rezidivierender Uveitis (ERU). Pferdeheilkunde 33, 112-118; DOI 10.21836/PEM20170201

Dorrego-Keiter E, Tóth J., Dikker L, Sielhorst J., Schusser G. F. (2016) Detection of leptospira by culture of vitreous humor and detection of antibodies against leptospira in vitreous humor and serum of 225 horses with equine recurrent uveitis. Berl. Münch. Tierärztl. Wschr. 129, 209-215

Dwyer A. E., Crockett R. S., Kalsow C. M. (1995) Association of leptospiral seroreactivity and breed with uveitis and blindness in horses: 372 cases (1986-1993). J. Am. Vet. Med. Assoc. 207, 1327-1331

Faber N. A., Crawford M., LeFebvre R. B., Buyukmihci N. C., Madigan J. E., Willits N. H. (2000) Detection of Leptospira spp. in the Aqueous Humor of Horses with Naturally Acquired Recurrent Uveitis. Clin. Microbiol. 38, 2731-2733

Fischer B. M., Mc Mullen R. J., Reese S., Brehm W. (2019) Intravitreal injection of low-dose gentamicin for the treatment of recurrent or persistent uveitis in horses: Preliminary results. BMC Vet. Res.; DOI 10.1186/s12917-018-1722-7

Frellstedt L. (2009) Equine recurrent uveitis: A clinical manifestation of leptospirosis. Equine Vet. Educ. 21, 546-552

Fritz K. L., Kaese H. J., Valberg S. J., Hendrickson J. A., Rendahl A. K., Bellone R. R., Dynes K. M., Wagner M. L., Lucio M. A., Cuomo F. M., Brinkmeyer-Langford C. L., Skow L. C., Mickelson J. R., Rutherford M. S., McCue M. E. (2014) Genetic risk factors for insidious equine recurrent uveitis in Appaloosa horses. Anim. Gen. 45, 392-399; DOl 10.1111/age.12129.

Frühauf B., Ohnesorge B., Deegen E., Boevé M. (1998) Surgical Management of equine recurrent uveitis with single port pars plana vitrectomy. Vet. Ophthal. 1, 137-151

Gerding J. C., Gilger B. C. (2016) Prognosis and impact of equine recurrent uveitis. Equine Vet. J. 48, 290-298; DOI 10.1111/ evi. 12451

Gerhards H., Wollanke B. (2001) Uveitis bei Pferden - Diagnose und Therapie. Pferdeheilkunde 17, 319-329; DOI 10.21836/ PEM20010402

Gilger B. C. (2010) Equine recurrent uveitis The viewpoint from the USA. Equine Vet. J. 42 (S37), 57-61

Gilger B. C., Allen J. B. (1998) Cyclosporine A in veterinary ophthalmology. Vet. Ophthal. 1, 181-187

Gilger B. C., Malok E., Stewart T., Ashton P., Smith T., Jaffe G. J., Allen J. B. (2000) Long-term effect on the equine eye of an intravitreal device used for sustained release of cyclosporine A. Vet. Ophthal. 3, 105-110

Gilger B. C., Salmon J. H., Na Y. Y., Barden C. A., Chandler H. L., Wendt J. A., Colitz C. M. (2008) Role of bacteria in the pathogenesis of recurrent uveitis in horses from the southeastern United States. Am. J. Vet. Res. 69, 1329-1335; DOI 10.2460/ ajvr.69.10.1329.

Gilger B. C., Wilkie D. A., Clode A. B., McMullen R. J., Utter M. E., Komaromy A. M., Brooks D. E., Salmon J. H. (2010) Long-term outcome after implantation of a suprachoroidal cyclosporine drug delivery device in horses with recurrent uveitis. Vet. Ophthal. 13, 294-300 DOI 10.1111/j.14635224.2010.00807.x.
Halliwell R. E., Brim T. A., Hines M. T., Wolf D., White F. H. (1985) Studies on equine recurrent uveitis. II The role of infection with Leptospira interrogans serovar pomona. Curr. Eye Res. 4, 1033-40

Heusser H. (1948) Die periodische Augenentzündung, eine Leptospirose? Schweiz. Arch. Tierheilk. 90, 287-314

Kleinpeter A., Göpfert A., Köhler E., Brehm W. (2019) Intravitreale Low-Dose-Gentamicininjektion zur Behandlung ERU-erkrankter Pferde / Intravitreal injection of low-dose gentamicin for the treatment of ERU-affected horses. Tierärztl. Praxis G; DOI10.1055/a-0816-7156

Kulbrock M., Lehner S., Metzger J., Ohnesorge B., Distl O. (2013a) A genome-wide association study identifies risk loci to equine recurrent uveitis in German warmblood horses. PLoS One 8, e71619; DOI 10.1371/journal.pone.0071619.

Kulbrock M., von Borstel M., Rohn K., Distl O., Ohnesorge B. (2013b) Studie zu Häufigkeit und Schweregrad der Equinen Rezidivierenden Uveitis bei Warmblütern. Pferdeheilkunde 29, 27-36; DOI 10.21836/PEM20130105

Lavach J. D. (1990) Large animal ophthalmology. St. Lovis: Mosby. McLaughlin, S. A., Whitley, R. D., Gilger, B. C. (1992) Diagnosis and treatment of lens diseases. Vet. Clin. North Am. Equine Pract. 8, 575-85

McMullen Jr. R. (2015) Intravitreal injection of low-dose gentamicin in horses for treatment of chronic recurrent or persistent uveitis: preliminary results. Conference Paper, International Equine Ophthalmology Consortium/Acrivet, Inc. Symposium

Niedermaier G., Wollanke B., Hoffmann R., Brem S., Gerhards H. (2006) Detection of leptospira in the vitreous body of horses without ocular diseases and of horses with equine recurrent uveitis (ERU) using transmission-electron microscopy. Deutsch. Tierärzt. Wschr. 113, 418-422

O'Brien J. M., Albert D. M., Foster C. S. (1994) Anterior uveitis. Principles and practice of ophthalmology. Philadelphia: Saunders, 1, 407-423

Pearce J. W., Galle L. E., Kleiboeker S. B., Turk J. R., Schommer S. K., Dubielizig R. R., Mitchell W. J., Moore C. P., Giuliano E. A. (2007) Detection of Leptospira interrogans DNA and antigen in fixed equine eyes affected with end-stage equine recurrent uveitis. Vet. Diagn. Invest. 19, 686-690; DOI $10.1177 / 104063870701900611$

Polle F., Storey E., Eades S., Alt D., Hornsby R., Zuerner R., Carter R. (2014) Role of Intraocular Leptospira Infections in the Pathogenesis of Equine Recurrent Uveitis in the Southern United States. J. Equine Vet. Sci. 34, 1300-1306; DOI 0.1016/i.jevs.2014.09.010

Rimpau W. (1947) Leptospirose beim Pferd (Periodische Augenentzündung). Tierärztl. Umsch. 2, 177-178

Schinagl C. (2017) Pars-Plana-Vitrektomie bei Equiner Rezidivierender Uveitis: Langzeitergebnisse zu Rezidivfreiheit, Sehfähigkeit und Bulbuserhalt bei 654 Augen von 549 Pferden. Diss. Med. Vet. München

Schwink K., Crisman M., Rigg D. (1989) Chronic recurrent uveitis in a horse with an elevated aqueous humor antibody titer to Leptospira interrogans serovar autumnalis. Equine Pract. 1 1, 41-43

Sillerud C. L., Bey R. F., Ball M., Bistner S. I. (1987) Serologic correlation of suspected Leptospira interrogans serovar pomona-induced uveitis in a group of horses. J. Am. Vet. Med. Assoc. 191, 1576-1578

Szemes P., Gerhards H. (2000) Untersuchungen zur Prävalenz der equinen rezidivierenden Uveitis im Grossraum Köln-Bonn. Prak. Tierarzt 81, 408-420

Tömördy E., Haessig M., Spiess B. M. (2010) The outcome of pars plana vitrectomy in horses with equine recurrent uveitis with regard to the presence or absence of intravitreal antibodies against various serovars of Leptospira interrogans. Pferdeheilkunde 26, 251-254; DOI 10.21836/PEM20100222

von Borstel M., von Oppen T., Glitz F., Frühauf B., Deegen E., Boeve M. H., Ohnesorge B. (2005) Langzeitergebnisse der Pars plana Vitrektomie (double port) bei equiner rezidivierender Uveitis. Pferdeheilkunde 21, 13-18; DOI 10.21836/PEM20050102 
von Borstel M., Oey L., Strutzberg-Minder K., Boevé M. H., Ohnesorge B. (2010) Direkter und indirekter Nachweis von Leptospiren aus Glaskörperproben von Pferden mit ERU. Pferdeheilkunde 26, 219-225; DOI 10.21836/PEM20100217

Werry H., Gerhards H. (1992) Zur operativen Therapie der equinen rezidivierenden Uveitis (ERU). Tierärztl. Praxis 20, 178-186

Werry H., Gerhards H. (1991) Möglichkeiten der und Indikationen zur chirurgischen Behandlung der equinen rezidivierenden Uveitis (ERU). Pferdeheilkunde 7, 321-331; DOI 10.21836/PEM19910602

Wiehen L. E. (2012) Retrospektive Analyse zum Vorkommen der Equinen rezidivierenden Uveitis - unter Berücksichtigung der Leptospireninfektion- an der LMU München von 01.2005 bis 06.2010 Diss. Med. Vet. München

Winterberg A., Gerhards H. (1997) Langzeitergebnisse der Pars-plana-Vitrektomie bei equiner rezidivierender Uveitis. Pferdeheilkunde 13,377-383; DOI 10.21836/PEM19910602

Wollanke B. (1995) Untersuchungen zur Ätiologie der equinen rezidivierenden Uveitis (ERU). Diss. Med. Vet. München
Wollanke B., Gerhards H. (2009) Equine rezidivierende Uveitis. Cont. Vet. Educ. 1, 1-14

Wollanke B., Gerhards H., Brem S., Kopp H., Meyer P. (1998) Intraokulare und Serumantikörpertiter gegen Leptospiren bei 150 wegen equiner rezidivierender Uveitis (ERU) vitrektomierten Pferden. Berl. Münch. Tierärztl. Wschr. 111, 134-139

Wollanke B., Gerhards H., Brem S., Meyer P., Kopp H. (2004) Ätiologie der equinen rezidivierenden Uveitis (ERU): Autoimmunkrankheit oder intraokulare Leptospireninfektion. Pferdeheilkunde 20, 327-340; DOI 10.21836/PEM20040403

Wollanke B., Gerhards H., Brem S., Wolf E., Kopp H., Meyer P. (2000) Zur Leptospirenätiologie der equinen rezidivierenden Uveitis (ERU): Ergebnisse der Untersuchungen von Serum-und Glaskörperproben. Tierärztl. Praxis 28, 153-158

Wollanke B., Rohrbach B. W., Gerhards H. (2001) Serum and vitreous humor antibody titers in and isolation of Leptospira interrogans from horses with recurrent uveitis. J. Am. Vet. Med. Assoc. 219, 795-800 